\title{
SIR WILLIAM HUME
}

William Errington Hume died on January 1, 1960, in his eighty-first year. He was born on July 14,1879 , the eldest son of George Haliburton Hume, Honorary Surgeon to the Newcastle Infirmary. His father's names show their Border ancestry for the village of Haliburton lies close to Hume, whose castle-crowned hill dominates the beautiful valley of Tweed which he loved so well.

Hume was educated at Repton and Pembroke College, Cambridge, before going on to the London Hospital where he clerked for Sir Bertrand Dawson, later Lord Dawson of Penn, with whom he formed a lifelong friendship. He graduated M.B., B.Ch. and was appointed to the Newcastle Infirmary in 1904, first as house surgeon and later as senior house physician, the post he held in 1906, when the present Royal Victoria Infirmary was opened. At this time he acted as secretary of the Honorary Staff and was deeply engaged in the transfer from the old hospital and the planning of the new.

In 1908, his appointment as Assistant Physician was the start of a career in consulting medicine which made him famous in the north-east of England and beyond. He was an outstanding success as a teacher, and his ward rounds and museum classes, successfully wedding pathology and clinical medicine, were extremely popular.

Heart disease was Hume's main interest from the first. He used the ink polygraph in an analysis of the arrhythmias and later, in 1913, he brought the electrocardiograph to Newcastle. He published A case in which high speed of the auricles did not produce tachycardia (Quart. J. Med., 1912-13, 6, 235) - one of the early descriptions of auricular flutter-and A polygraphic study of four cases of diphtheria (Heart, 1913-14, 5, 25). His work on the changes of rhythm and on the pathology of the heart in diphtheria was well known.

In the first world war he became a Lieutenant-Colonel in the First Northern General Hospital T.F., but wanting a more active role he took a lower rank to join a Casualty Clearing Station. Later, he was posted to Boulogne to help Dawson at the base hospitals there. He did important work in the organization of centres for the treatment of soldiers with suspected heart dysfunction, then known as D.A.H., and with Dawson and Bedson on spirochætal jaundice among the troops. While at Boulogne, he met the lady who was to become his wife, the daughter of a distinguished officer of the French Army. Later he was appointed Consulting Physician to the 1st Army in France, and worked on poison gases. He was twice mentioned in despatches and received the honour of C.M.G.

On his return from the army, he wrote about the effects of war nephritis and in the early 1920's about encephalitis lethargica. He soon became one of the leading physicians in the North of England. He lectured in pharmacology and medicine before succeeding to the Chair of Medicine in the Medical School of Newcastle. His lectures were models of sound practical instruction, vividly illustrated by cases from his own practice which were presented in such a way that the student felt as though he were at the bedside with the lecturer. His ward rounds had the same fascinating quality and always drew a full house.

His activities were not confined to Newcastle. The Royal College of Physicians made him Bradshaw lecturer, and as his subject he chose Paroxysmal Tachycardia (Lancet, 1930, 2, 1055). He became Senior Censor of the College in 1941 and was appointed Harveian Orator in 1943. He spoke on The Physician in War-in Harvey's Time and After and his sense of history helped him in tracing Harvey's journeys to the North with Charles I. He also examined in Medicine for the Universities of Cambridge, Edinburgh, London, Liverpool, and Leeds. He was always described as a formidable but kindly examiner, who insisted on a good clinical approach and had no use for the candidate who knew all about the blood calcium but did not know how to obtain a knee-jerk. 


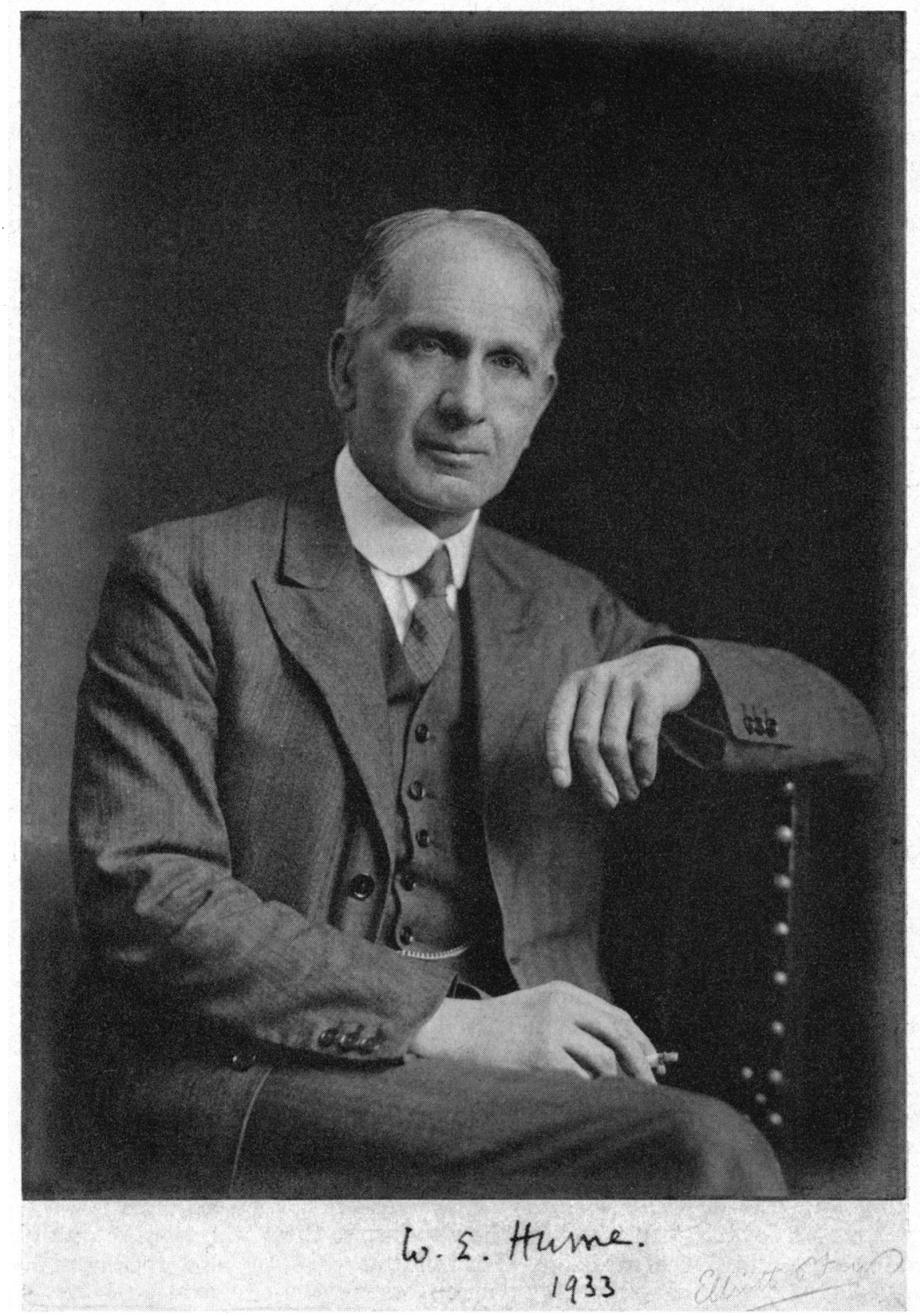

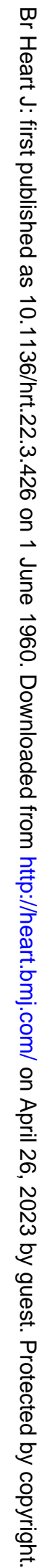


After his retirement from the Honorary Staff of the Royal Victoria Infirmary in 1939 he moved to the Newcastle General Hospital which was expanding under the influence of Dr. John Charles, later Sir John, then Medical Officer of Health of the city, and was able to concentrate his interests on cardiology, which he foresaw would need to be treated as a special branch of medicine. It was largely through his efforts that a Regional Cardiovascular Department was set up at Newcastle General Hospital. The plans were well advanced before the State took over and the inauguration was held in 1950, unhappily in his absence for already his health had begun to fail. From this time he became increasingly invalid from arthritis and soon was unable to walk more than a short distance. Other disabilities followed in distressing sequence but his mind never flagged and remained clear and active to the end. He took great pleasure in research into local medical history and he compiled the history of the Infirmary for its bicentenary celebrations.

Hume took an active part in the introduction of the National Health Service. He always maintained that a patient should have easy access to the best medical services, no matter where he lived, and in those days there were many places in the industrial North where medical conditions were somewhat primitive. He was one of the original members of the Regional Hospital Board and he exerted himself in this capacity, and as Adviser in Medicine to the Board, to ensure that his views were heard. His active interest in the work of the young physicians who were appointed to the outlying posts was greatly appreciated. He was knighted in 1952. Professor F. J. Nattrass writes as follows. "Hume's hospital career began at so early an age and lasted so long that it was possible for a man now retired from hospital to think of him as teacher, colleague, and personal friend. He was appointed assistant physician to the Royal Victoria Infirmary at the age of 28 and full physician six months later; and in his thirties he was consulting physician to an army in France. There is food for thought when one compares the possibilities in these days."

Hume was one of the founders of the Cardiac Society, for on February 21, 1922, he wrote to John Cowan suggesting that those physicians who had been meeting to advise the Ministry of Pensions on matters relating to heart disease should be called together at the next meeting of the Association of Physicians. This meeting took place at Oxford with A. G. Gibson in the chair, and on April 22, 1922, the Cardiac Club was born. Hume was our Chairman at the Newcastle meeting in 1926 and in the early days of the society he opened several discussions-on the effects of adrenalin in 1924, on the heart in diphtheria in 1932, and (with Cotton) on heart symptoms and gall-bladder disease in 1935. When he was again Chairman in 1953, he and his wife entertained the Council to dinner in their home before the Council meeting, and some of those present felt it might be the last occasion when such a dinner was served in such gracious style and surroundings in a private house. We were delighted that his health allowed him to preside at this meeting, for it was the last time that many of our members saw him.

In appearance Hume was a typical Borderer. Tall and big-boned, he was an impressive figure and in later years his limp seemed to give him an added dignity. His features were strong and handsome. The eyes were a steely blue and could be very disconcerting when they were levelled at his interlocutor until, as usually happened, his face softened into a charming smile.

Country life and country people were much to his liking. He gave up golf for salmon fishing in Tweed, where he was a well-known member of the angling fraternity centred round Cornhill and Tillmouth. His generosity in giving his rod for the day to junior aspirants to the gentle art will long be remembered with gratitude.

Hume was a most lovable man who knew how to inspire those who worked with him with his own consuming interest in clinical medicine. His residents, registrars, and nursing staff adored him and in later years there were several moving reunions which gave him great pleasure. He was one of the great clinicians of the first half of this century who blazed the trail that we are now following and we shall not see his like again.

To his widow, three daughters, and two sons, one of whom follows him in medicine, we extend our deep sympathy in their loss.

$$
\text { W. G. A. SWAN }
$$

